\title{
HUMAN CAPITAL FORMATION USING BUSINESS SIMULATION MODELS
}

\author{
Solveiga Skunčikienė
}

Andrius Rakickas

Siauliai University, Lithuania

\begin{abstract}
The subject of the analysis in this paper is human capital formation at the individual level, applying business simulation models as a learning tool that meets requirements of the modern learning process that should include and link personal experience, encourage thinking, acquisition of new knowledge, formation of new experience and its application in analysing practical situations.

The subject of the research paper: human capital formation using business simulation model. The aim of the research - to analyze the application possibilities of business simulation models for the human capital formation.

To achieve the aim of the research the following tasks were set: to disclose the concept of business simulation model; to validate the applicability of business simulation models for human capital formation on the basis of empirical research.

The subject of the analysis in this paper is human capital formation at the individual level, applying business simulation models as a learning tool that meets requirements of the modern learning process that should include and link personal experience, encourage thinking, acquisition of new knowledge, formation of new experience and its application in analysing practical situations.

Research methods: analysis of scientific literature using operations of analysis and synthesis, comparison and systematization, questionnaire survey, and the following methods of statistical data analysis.
\end{abstract}

Keywords: business simulation models, human capital, human capital formation.

\section{Introduction}

Today, in a rapidly changing environment, organisations have to meet more and more requirements in order to be successful. Traditional resources such as labour, land and capital, are no longer considered to be the main sources of organisational development (Skunčikienè, Rakickas, Patašienė, 2015). Despite the proliferation of human capital definitions in the literature, a number of key elements seem to be common, encompassing knowledge, education, experience, health, competence, trained skills and endowed abilities (Poteliene, Tamašauskiene, 2014). According to P.C. Ildikó (2011), competence, knowledge 
and skills directly influence working efficiency. Human capital can be assessed at individual, organizational and state levels. Individual and organisational levels of human capital in most cases are assessed by scientists of management and labour economics by analysing employees' abilities and intellectual resources in order to improve and develop its applicability aiming increase an organization's profitability and employees' motivation.

At national level, sociologists and economists analyse the state's labour quality, compare with that in other countries and form proposals on improving human capital abilities at the national and regional level (David Lopez, 2001). According to the results of scientific literature analysis and studies of different scientists, it can be said that human capital accumulation (especially through education) provides benefits for both individuals and enterprises (organizations), as well as society as a whole. The benefits can have both economic nature (determine additional revenue, productivity and economic growth) and wide range non-economic (non-cash) nature, including greater social cohesion, less crime, better public health and implementation of new technologies and innovations in the national economy.

The subject of the research paper: human capital formation using business simulation model.

The aim of the research - to analyze the application possibilities of business simulation models for the human capital formation.

To achieve the aim of the research the following tasks were set:

- $\quad$ to disclose the concept of business simulation model;

- $\quad$ to validate the applicability of business simulation models for human capital formation on the basis of empirical research

The subject of the analysis in this paper is human capital formation at the individual level, applying business simulation models as a learning tool that meets requirements of the modern learning process that should include and link personal experience, encourage thinking, acquisition of new knowledge, formation of new experience and its application in analysing practical situations.

Research methods: analysis of scientific literature using operations of analysis and synthesis, comparison and systematization, questionnaire survey, and the following methods of statistical data analysis.

\section{The results of an application of the business simulation model to human capital formation}

The object of the paper is an analysis of human capital formation at the individual level, applying business simulation models as a learning tool that meets requirements of the modern learning process that should include and link personal 
experience, encourage thinking, acquisition of new knowledge, formation of new experience and its application in analyzing practical situations.

It is believed that in order to predict the new working place requirements, organizations need to apply learning methods and techniques that have ability to achieve effective results with the minimal costs and period of time.

Therefore, in choosing learning methods, a new trend is observed (Baležentis, 2008):

- a shift from traditional teaching methods such as lectures, seminars and others to grouping learning methods that encourage learners' own activity and develop teamwork skills;

- a shift from teaching to self-learning, the importance of which is growing, as well as competition in the labor market and the emergence of new learning technologies.

In today's society, particular attention is given to technologies and their development, so more and more attention is attracted by business simulation models and their application to various levels of educational institutions and training organizations. A simulation business model is based on economics, management, finance and other scientific laws and rules, using real or simulated business/country data, which is realized for participants in the decision-making process in accordance with certain rules and roles.

A simulation business model's objectives, activities, roles, limitations, consequences and the relationships between them imitate reality elements. Characterizing the simulation business model, it is important to mention the fact that it reveals and emphasizes the interaction process, but not the individual performance of roles (Patašienè, Rakickas, Skunčikienè, Patašius, 2014). This kind of environment creates ideal conditions for human capital formation, e.g. the dissemination of new knowledge and experience, skills, the adaptability of competencies for solving practical problems (Bagdonas, Patašiene, Skvernys, 2003; Skunčikienè, Rakickas, 2006; Klabbers, 2009; Skunčikienè, 2008; Duke, Kriz, 2014, Skunčikienè, Rakickas, Patašienè, 2015).

It is the presumption that during the learning process of the business simulation model, learners in a relatively short period of time can reveal and develop both innate and acquired personal qualities, acquire the necessary business knowledge, develop social skills. Various professionals can develop skills that are required in any professional activities and to develop entrepreneurial competence, because it is analyzed in simulated business situations (Skunčikiene, 2008).

In order to justify the business simulation model's applicability to human capital formation, its benefits and expediency, on December in 2016 an empirical study was done. For the questionnaire, during the research, target respondents were taken - 20 employees from one organization operating in Lithuania and 
being engaged in trade and services. In such a kind of empirical study, it is believed that this number of respondents is sufficient, and the results of the study are representative. The number of respondents was chosen due to the specifics of the investigation as the semi-experimental study was carried out while interviewing the respondents before and after the business simulation.

The research instrument was an anonymous questionnaire, which consisted of questions about respondents' personal data, learning environments, learning methods, needs to develop general skills and their educational opportunities through business simulation models (Skunčikienè, 2008).

Most of the questions in the questionnaire were of a closed or semi-closed type. To investigate the respondents' opinion, there was used the Likert scale, where respondents evaluated any assertion on an appropriate ranking scale (options were: always, often, sometimes, never, I do not know).

The research applied part of a computerized micro-level business simulator, which included one of the company's economic activities under conditions of perfect competition. Computerized business simulation is realized when participants work in groups to make decisions in record sheets. Instructors of this activity entered adopted decisions into a special computer program; the computer program processes the data and provides new information to learners. Learners adopted 228 decisions; the instructor of this activity adopted 123 decisions. It is also possible to provide additional information about the individual working groups to present the results and graphs.

One of the tasks of the research was to determine what main learning motives of the respondents were and what reasons for employees were to learn: whether learning was related to personal or an organization's development needs.

The data analysis showed that the respondents' learning process was mainly linked to the organization's development $(70 \%)$ and to the organization's objectives and their realization (30\%). None of the respondents chose the answer that they studied to get a higher qualification level and to get a higher salary. It can be argued that such a distribution of the respondents indicate that learning is seen as an integral factor in the development of the organization, which is directly linked with the modern concept of a learning organization where learning is supported and encouraged at the individual, group and organizational levels. It is assumed that the organization, in order to set goals, create the right conditions for staff training, i.e. create appropriate material and other conditions to support the learning process.

Based on the research results, it can be said that in the organization, there is a great need for cooperation, sharing of knowledge, experience and skills, which help the organization to achieve its goals. $85 \%$ of the respondents said that the organization had a flexible wage system, $70 \%$ respondents noted that employees were financially encouraged to improve themselves. These answers indicate that 
a financial improvement system was created in the analyzed organization. $85 \%$ of the respondents said that the employees respected each other and were tolerant, $75 \%$ of the respondents said that they were open and trusted each other, $85 \%$ the respondents felt responsibility for each other and for the organization itself. The employees' answers reflected the high culture of communication in the organization.

Bonuses, premiums, promotion and similar measures can be used as one of employee motivation tools, and it is enough for some people that after completion of a successful project they feel an increased sense of self-esteem or learn something new.

The research results showed that a learning assessment system for workers should be created in the organization, because only $25 \%$ of the respondents said that it was created. Employees who participate in training hope that they will be more useful for the organization and will appreciate it. If a learning assessment system is not established, then the criteria are not set.

The learning process in the organization is perceived as a natural process, and then high culture is formulated, which affects workers' respect and tolerance, openness and trust, responsibility for each other and for the organization itself. Half of the respondents $(50 \%)$ pointed out that they always evaluated themselves to know what knowledge and skills they needed in their professional activities and asked the head of the organization to be involved in this kind of training.

The respondents also noted (44\%) that the head of the company made staff surveys on training needs and assessed the company's performance and offered employees to study ( $7.7 \%$ - always, $23.1 \%$ - often, $30.8 \%$ - sometimes). The results showed that more than a half of all the respondents $(55 \%)$ once per quarter participated in various training events, $45 \%$ - once per half year.

In summary, it can be concluded that quite frequent participation in the training process by the respondents was associated with high requirements for the personnel working in the analyzed organization.

The results of research showed that more than a half of the respondents identified their workplace often $(65 \%)$ and always $(20 \%)$ as the dominant learning place. It can be assumed that employees realize that by doing routine work in the organization, sharing knowledge, experience during chat and discussions they learn from each other, i.e. learning and work processes are not separated. A high proportion of the respondents (40\%) always learns and asks for advice and instruction from supervisors or other employees with greater experience.

The results showed that in the organization traditional teaching and learning methods were often applied, because $85 \%$ of the respondents said that they participated in various seminars, courses and lectures, $35 \%$ often and $60 \%$ sometimes analysed the professional literature. The subject knowledge and 
professional information can be acquired using this kind of teaching-learning method.

$80 \%$ of the respondents said that they used computer programs and the Internet for learning. It is not just learning how to use the Internet, but the Internet is used as a learning tool (e.g., to forward tutorial material etc.), as well as other computerized applications. During computerized training, employees can deepen and develop professional knowledge and necessary skills.

$80 \%$ of the respondents said that the organization applied job rotation, i.e. transfer of staff from one job to another. This is confirmed by the results that the organization gives every opportunity for an employee to expand their experience and get acquainted with the various aspects of the organization's activities. It is considered that the rotation of duties mainly is used for the acquisition and development of managerial and professional knowledge. Also, the study showed that teaching-learning methods such as simulation of business models were rarely applied by external consultants.

Summarizing results of the research, it can be said that the analyzed organization is a modern learning organization, because this organization tries to ensure continuous learning at all levels of the organization, constantly analyzing employee training needs, coordinates them with the organization's goals and creates an environment to its satisfaction.

It is considered that an organization has an ongoing process of learning (at individual, group, organization levels), which mainly involves and promotes toplevel managers' training needs and understanding, and for employees, the training-learning process is not a fragmented process, which is limited to regular seminars or raising the qualification in specialized institutions, but it is supported and held within the organization. The learning process should include and link the employee's experience, promote thinking, a new experience in the design and application of practical situations analysis.

Analyzing the teaching-learning process, it should be noted that learning takes place because of the organization's need to adapt to a changing environment. It is emphasized that this is only possible when top managers consider not only individual and/or group-level learning but also the cultural formation of the entire organization a key management task for the organization, with the involvement of all employees in general organizational strategy formulation, allowing everyone to use all relevant information, constantly to experiment and grow, i.e. to support the idea of a learning organization. Employees, during the teachinglearning process, complement already existing and form new knowledge, abilities, skills and experience, developing competencies that are needed in their professional activities.

An evaluation and development of workers' personal characteristics are important, because part of an individual's personal characteristics are acquired or 
congenital and can unfold only in an environment which will enable them to actively communicate, collaborate, share knowledge and experience or in professional activities.

It is considered that in professional activities an employee's personal characteristics are important, because they may partly depend on other skills. Before making the simulation modelling of business, the respondents were asked what personal characteristic were required in their professional activities. Summarizing the respondents' choices (expressed as a percentage), it should be noted that most workers, in their professional activities, required such personal characteristics as initiative, analytical thinking, quick orientation in a critical situation, independence (100\%), diplomacy, activity, communication and creativity $(95 \%)$.

The research results showed that after an application of a business model, the majority of the respondents were able to identify and develop both innate and acquired personal characteristics, such as activity (100\%), independence $(90 \%)$, analytical thinking ( $85 \%$ ), creativity $(80 \%)$, communication skills $(90 \%)$, less charisma (40\%).

Based on the results of the study, it should be noted that the business simulation model enables employees to develop their acquired and innate personal characteristics that are needed for their professional activities.

It was also analyzed what kind of skills employees generally need at their workplaces and what skills were developed during the business simulation.

According to the research data, it was found that workers in their professional activities usually needed such skills as work planning and organization, communication (100\%), the planning of the organization's unit activity (95\%), problem identification, resolution and control (90\%), less - public presentations (45\%), a foreign language (35\%).

The results of the respondents' questionnaires after the simulation business process showed that during the business simulation employees were able to develop these skills: how to work in team, communicate, analyze the consequence of decisions taken, integrate knowledge and seek rational operational decisions $(100 \%)$, predict activities (95\%), to plan activities (83\%) and look for custom solutions $(80 \%)$.

In summary, during the business simulation, the employees of the organization were able to acquire and develop the general and professional skills, which they needed for their professional activities.

Economic, financial and management skills are associated with the interprofessional competence, with the emphasis being placed on the individual disciplines of knowledge (economics, management, computer science, etc.), which are necessary for everyone in daily life, at work, in society and allows 
employees better to understand their professional context and to make better use of opportunities.

Analyzing the research results, it was found that before the business simulation the majority of the respondents said that they usually needed management knowledge, such as understanding of interconnectedness of organizational units (100\%), competitor analysis (95\%), marketing analysis tools (75\%), financial expertise such as financial analysis and information $(75 \%)$, analysis of financial indicators ( $80 \%$ ), cash flow management $(60 \%)$, economic knowledge such as pricing (95\%), perception of service development and the delivery process, analysis, planning and management (95\%), lending and saving principles $(75 \%)$, production process analysis and management $(65 \%)$.

After the business simulation, the respondent's answers showed that most of the respondents acquired management knowledge, such as selection and analysis of marketing tools $(100 \%)$, competitor analysis (90\%), understanding of interconnectedness of organizational units $(75 \%)$, financial expertise such as financial analysis indicators $(100 \%)$, cash flow management $(90 \%)$, financial information analysis $(90 \%)$, economic knowledge such as pricing $(100 \%)$, analysis and management of the production process (100\%), perception of service development and the delivery process, analysis, planning and management (95\%), lending and saving principles (90\%).

Summing up results, it can be said that the need of respondents' management, financial and economic knowledge and skills of business simulation modelling is satisfactory, i.e. workers during a relatively short period of time gained the necessary managerial, financial and economic expertise and business capacity. Using business simulation methods, the learning process exists not only in a right, but also in a wrong way of making decisions and learning from mistakes. Learners have an opportunity to immediately review and discuss the results of decisions made, share experiences (Poonnawata, Lehmanna, 2014). Such activity creates a safe learning environment where learners feel safe even taking wrong decisions, because errors are perceived as a learning process. It should be noted that during business simulation a learning environment is creating that promotes curiosity, reduces the fear of making mistakes, errors are discussed, analyzed, lessons are learnt from them and it is searched for reasons why the decision was wrong (Skunčikienè, Rakickas, Patašienè, 2015).

\section{Conclusions}

The comparative analysis of the scientific literature suggests that the main components of human capital are knowledge, personal/innate qualities, skills and abilities, education, experience, competence, emotional and the mental state of 
health, and so on (Potelienè, Tamašauskienè, 2014), but education is singled out as the most important element of human capital.

Summarizing the study results, it can be said that the business simulation model can be applied to the employee's human capital formation, e.g. team / group work competency development, seeking for a leader and the disclosure of their personal qualities, sharing of business experience, knowledge integration and the acquisition of new knowledge (economics, finance and management), searching for rational methods of operation, entrepreneurship competence development, problem identification and decision-making, planning and emotional management skills development, taking into account all the learning needs.

\section{References}

Bagdonas, E., Patašienè, I., Skvernys, V. (2003). Kompiuteriniai verslo žaidimai - tiltas tarp žiniu ir praktines veiklos. Transformacijos Rytų ir Centrinejje Europoje: žurnalo „Tiltai““ priedas Nr. 13.

Baležentis, A. (2008). Inovatyviuju mokymo formu ir metodu taikymo galimybės žmogiškuju ištekliu vadyboje. Viešoji politika ir administravimas (pp. 97-104). Vilnius: MRU, Nr. 26.

David, P. A., Lopez, J.G.G. (2001). Knowledge, Capabilities and Human Capital Formation in Economic Growth. Downloaded from: http://www.treasury.govt.nz/publications/ research-policy/wp/2001/01-13/twp01-13.pdf

Duke, R. D., \& Kriz, W. C. (2014). Back to the future of gaming. Bielefeld: W. Bertelsmann Verlag.

Ildiko, P.C. (2011). Analysis of Human Capital Among the Types of Higher Education Institutions Offering Economics Programs at ABC level. $\mathrm{PhD}$ thesis. University of West Hungary.

Klabbers, J. H. G. (2009). The magic circle: principles of gaming and simulation. Rotterdam: Sense publishers.

Patašienè, I., Rakickas, A., Skunčikienè, S., Patašius, M. (2014). Increasing complexity of business simulations and games is expected in the future. Back to the future of gaming. W. Bertelsmann Verlag.

Potelienè, S., Tamašauskienė, Z. (2014). Žmogiškojo kapitalo konceptualizacija: raida, samprata ir formavimas. Verslo sistemos ir ekonomika (pp. 89-106) Vilnius: MRU, Nr. 4 (online).

Poonnawata., W., Lehmanna, P. (2014). A Framework of using DSS in Business Simulation Games Study Object: Business Intelligence and Corporate Performance Management Downloaded from: http://dss20conference.files.wordpress.com/2014/05/poonnawat.pdf

Skunčikienè, S., Rakickas, A. (2006). Entrepreneurship education and training of the business games in the modern society. Riga International School of Economics \& Business Administration (Riga, Latvia) / an International Scientific Conference The Next Decade Challenges For Business, Riga.

Skunčikienè, S. (2008). Imitaciniu verslo žaidimu taikymo vertinimas besimokančioje organizacijoje. Daktaro disertacija. Kaunas: VDU leidykla. 
Solveiga Skunčikienè, Andrius Rakickas. Human Capital Formation Using Business Simulation Models

Skunčikienè, S., Rakickas, A., Patašienè, I. (2015). Socialinių-ekonominiu procesu Lietuvoje raidos prieštaros (teorija ir praktika). Mokslo studija (pp. 75-104). Šiauliai: BMK leidykla. 